\title{
Invited Discussion on: Anchor-Line Abdominoplasty with Scarpa's fascia Preservation in Postbariatric Patients: A Comparative Randomized Study
}

\author{
Osvaldo Saldanha $^{1}(\mathbb{D})$ Carlos Goyeneche $^{1} \cdot$ Andrés I. Ordenes $^{1} \cdot$ Cristianna Bonetto Saldanha $^{1}$
}

Received: 10 December 2019/Accepted: 11 December 2019/Published online: 20 December 2019

(C) Springer Science+Business Media, LLC, part of Springer Nature and International Society of Aesthetic Plastic Surgery 2019

Level of Evidence $V$ This journal requires that authors assign a level of evidence to each article. For a full description of these Evidence-Based Medicine ratings, please refer to the Table of Contents or the online Instructions to Authors www.springer.com/00266.

Since Lockwood [1, 2] and Louarn's [3] publications, in several other articles about lipoabdominoplasty [4], the preservation of Scarpa's fascia has been the subject of studies about its rate of complications and postoperative outcomes, additionally with many studies comparing complication rates of lipoabdominoplasty with abdominoplasty, including related to the formation of seroma [5-9].

There are two studies that tried to show the relationship of Scarpa's fascia to the lymphatic drainage of the lower abdomen: one showed that they are not preserved [10], and the other showed that they are preserved on the subfascial plane [11]. Another theory is that Scarpa's fascia decreases dead space and has an adherence on the remnant tissue [12].

Our experience with lipoabdominoplasty with preservation of Scarpa's fascia in more than 1500 patients, since the year 2000, has shown no cases of seroma (early or late) except in four cases in which we resected it.

This is an interesting well-structured work that aims to evaluate the importance of preserving Scarpa's fascia in anchor-line abdominoplasty to reduce seroma formation. Although there are a growing number of studies that focus

Osvaldo Saldanha

clinicasaldanha@hotmail.com

1 Serviço de Cirurgia Plástica Osvaldo Saldanha, Division of Plastic Surgery, Universidade Metropolitana de Santos, Av. Ana Costa, 146, complemento 1201 - 04, Santos, São Paulo 11060-000, Brazil on abdominal plastic surgery in post-bariatric patients, there is a lack in the literature about the preservation of Scarpa's fascia in this procedure [13, 14].

This is a comparative study between two randomized groups, with and without preservation of Scarpa's fascia, with 21 patients in each group, from May 30, 2014, to May 30,2015 , operated on at the author's private clinic. The authors consider seroma when the volume is larger than $30 \mathrm{ml}$. They demonstrated that both the drain removal time and the drain output volume in $24 \mathrm{~h}$ had a statistically significant decrease in the group of patients in whom Scarpa's fascia was preserved, although there was no difference in the rate of seroma formation in the two groups where the control was done by ultrasound at the 20th postoperative day.

There was also no difference in skin suture tension between the groups. Prophylaxis for DVT was not used either intraoperatively or postoperatively, and early ambulation was encouraged at the first postoperative day.

Drains were removed when drain output was less than $30 \mathrm{ml} / 24 \mathrm{~h}$. It would be interesting if the authors considered adding the results on a table showing the drain output day by day, until the drain is removed. It seems that the authors made a mistake when they spelled the quote "On ultrasound, fluid collections of 42.5, 61.4 and $103 \mathrm{ml}$ were observed for three patients in the fascial dissection group $\mathrm{A}$, and collections of $44.3,57.9$ and $193.9 \mathrm{ml}$ were observed for three patients in the fascial preservation group B" because in Table 2 it is the opposite where they showed that the maximum fluid collection in the group $\mathrm{A}$ was $193.9 \mathrm{ml}$ and in the group B corresponded to $103 \mathrm{ml}$.

Ultrasound screening for seroma around the 30-40th- or 50th-day ultrasound could be a valuable measurement to identify whether the same or larger volume still resided. 
Therefore, it could prove or rule out the diagnosis of late seroma.

Seroma, although it is the subject of great debate, does not represent a significant complication because it is easily treatable. However, the rate of this complication is shown to be low when Scarpa's fascia is preserved. Likewise, the quilting suture has also presented these same low rates [1517].

With the current knowledge of the predictive factors of DVT, it is known that post-bariatric patients fall into this context. Thus, its use would be recommended, accompanied by a future observational study.

The authors of this article open this interesting discussion that should stimulate new publications on the subject. I congratulate the authors for their work that is another reinforcement to the importance of Scarpa's fascia preservation in abdominoplasty.

\section{Compliance with Ethical Standards}

Conflict of interest The authors declare that they have no conflicts of interest to disclose.

Statement of Human and Animal Rights, or Ethical Approval This article does not contain any studies with human participants or animals performed by any of the authors.

Informed Consent For this type of study informed consent is not required.

\section{References}

1. Lockwood TE (1991) Superficial fascial system (SFS) of the trunk and extremities: a new concept. Plast Reconstr Surg 87(6):1009-1018

2. Lockwood TE (1995) High-lateral-tension abdominoplasty with superficial fascial system suspension. Plast Reconstr Surg 96(3):603-615

3. Le Louarn C (1996) Partial subfascial abdominoplasty. Aesth Plast Surg 20:123-127

4. Saldanha OR, Federico R, Daher PF, Malheiros AA, Carneiro PR, Azevedo SF et al (2009) Lipoabdominoplasty. Plast Reconstr Surg 124:934-942
5. Costa-Ferreira A, Rebelo M, Vásconez LO, Amarante J (2010) Scarpa fascia preservation during abdominoplasty: a prospective study. Plast Reconstr Surg 125:1232-1239

6. Costa-Ferreira A, Rebelo M, Silva A, Vásconez LO, Amarante J (2013) Scarpa fascia preservation during abdominoplasty: randomized clinical study of efficacy and safety. Plast Reconstr Surg 131:644-651

7. Di Martino M, Nahas FX, Barbosa MV, Ayaviri NA, Kimura AK, Barella SM et al (2010) Seroma in lipoabdominoplasty and abdominoplasty: A comparative study using ultrasound. Plast Reconstr Surg 126:1742-1745

8. Seretis K, Goulis D, Demiri EC, Lykoudis EG (2017) Prevention of seroma formation following abdominoplasty: a systematic review and meta- analysis. Aesthet Surg J 37:316-323

9. Samra S, Sawh-Martinez R, Barry O, Persing JA (2010) Complication rates of lipoabdominoplasty versus traditional abdominoplasty in high-risk patients. Plast Reconstr Surg 125(2):683-690

10. Tourani SS, Taylor GI, Ashtom MD (2015) Scarpa Fascia preservation in abdominoplasty: Does it preserve the lymphatics ? Plast reconstr Surg 136(2):258-262

11. Friedman T, Coon D, Kanbour-shakir A, Michaels J V, Rubin LP (2015) Defining de lymphatic system of the anterior abdominal wall: an anatomical study. Plast Reconstr Surg. 135(4):1027-1032

12. Har-Shai L, Hayun Y, Barel E, Add-El DD (2018) Scarpa fascia and abdominal wall deep adipose compartment preservation in abdominoplasty-current clinical and anatomical review. Harefuah 157(2):87-90

13. Correia-Gonçalves I, Valença-Filipe R, Carvalho J, Rebelo M, Peres H, Amarante J et al (2017) Abdominoplasty with Scarpa's fascia preservation-comparative study in a bariatric population. Surg Obes Relat Dis 13:423-428

14. Costa LF, Landecker A, Manta AM (2004) Optimizing body contour in massive weight loss patients: the modified vertical abdominoplasty. Plast Reconstr Surg 114(7):1917-1923

15. Pollock H, Pollock T (2000) Progressive tension sutures: a technique to reduce local complications in abdominoplasty. Plast Reconstr Surg 105(7):2583-2586 discussion 2587-2588

16. Andrades P, Prado A (2007) Composition of postabdominoplasty seroma. Aesthetic Plast Surg 31:514-518

17. Nahas FX, Ferreira LM, Ghelfond C (2007) Does quilting suture prevent seroma in abdominoplasty? Plast Reconstruct Surg 119:1060-1064

Publisher's Note Springer Nature remains neutral with regard to jurisdictional claims in published maps and institutional affiliations. 